\title{
sciendo
}

\section{The pre-pandemic role of customer online satisfaction in price determination: evidence from hotel industry}

\author{
Irena Palić \\ Faculty of Economics and Business, University of Zagreb, Croatia, \\ ipalic@efzg.hr \\ Petra Palić \\ Catholic University of Croatia, Croatia, petra.palic@unicath.hr \\ Frane Banić \\ Croatian National Bank, Zagreb, frane.banic@hnb.hr
}

\begin{abstract}
This study examines the importance of online reviews for price determination in the hotel industry in the pre-pandemic period. The research is conducted for Croatian small open economy with a developed tourism sector. The paper fills the gap in existing literature by using multivariate principal component analysis to group various customer satisfaction categories in the hotel industry and assessing the relationship between customer satisfaction and hotel price. The conducted empirical analysis points to a positive statistically significant relationship of guest satisfaction and hotel prices. Moreover, linear regression modelling is conducted separately for four-star and five-star hotels. The estimated impacts are statistically significant and positive, but the effects are twice as strong in five-star hotels then in four-star hotels. The obtained results indicate that hotel star rating impacts the strength of the relationship between hotel prices and guest satisfaction. Recognizing the link between hotel ratings, online reviews and pricing is essential both for hotel managers and customers. Hence, the paper provides valuable conclusions from the aspect of supply and demand side in the hotel industry.
\end{abstract}

Keywords: customer satisfaction, hotel pricing, hotel star rating, multivariate analysis, principal component analysis, regression analysis.

JEL classification: C38, L83, Z3, Z32.

DOI: $10.2478 /$ crebss-2021-0009

Received: October 12, 2021

Accepted: November 02, 2021

\section{Introduction}

Customer satisfaction, which is often considered as one of the most important nonfinancial metrics in business (Farris et al., 2015), is important for companies' growth and profitability (Matzler et al., 2006). Homburg et al. (2005) point to the existence of strong positive relation between consumer satisfaction and willingness to pay. 
Moreover, Bolton and Lemon (1999), Homburg et al. (2005) point to the suitability of equity theory, which states that for price-satisfaction relationship. The equity of payment refers to the change in customer rating of the fairness of received gain from service concerning the payment for service.

On the one hand, customers have higher expectations when they pay more for the service (Matzler et al., 2006). Previous studies in the hospitality industry indicate that price has an important role in consumer perceptions of quality (Bojanic, 1996, Mattila, O'Neill, 2003, Lewis, Shoemaker, 1997), although there is no consensus regarding the impact of service price on consumer perceptions. On the other hand, the opposite direction of the mentioned relationship reveals the importance of consumer satisfaction for companies' profitability. Consumer satisfaction is a major factor in achieving customer loyalty enhancement, which consequently boosts companies' business (Gronholdt et al., 2000). Namely, consumer satisfaction measured by online reviews can influence the service price and consequently companies' performance (Öğüt, Onur Tas, 2012). Regarding the analysis of customer satisfaction in the hospitality industry, online reviews as a possible measure of consumer satisfaction are important since potential consumers use the service sporadically, often purchase the service at a distance and have limited direct information on service quality (Viglia et al., 2016). Online reviews are considered complementary to word-of-mouth in online variant. Nevertheless, word-of-mouth operates through verbal communication, while online reviews are available to all potential consumers with internet access. In addition, online reviews are durable and more detailed than word-of-mouth (Öğ̈t, Onur Tas, 2012). Steffes and Burgee (2008) indicate that electronic word of mouth (eWOM) is as relevant as receiving purchasing advice from a reliable friend. The main research question is how customer satisfaction affects pricing in the hotel industry. Based on previous relevant literature provided in the next chapter, two main research hypotheses are stated. The first research hypothesis is: "Customer satisfaction has a positive statistically significant impact on hotel prices." The second research hypothesis is: "Customer satisfaction has a stronger influence on hotel pricing in five-star hotels than in fourstar hotels".

Current COVID-19 pandemic crisis affected the hotel industry like no other crisis before. Such closures and restrictions have never happened before. Nevertheless, the impact of online satisfaction on pricing still remains an important issue for both the demand and supply side in the hotel industry. Therefore, this research analyses the pre-pandemic impact of customer online satisfaction on hotel industry pricing in the stable pre-pandemic year in order to address solely the impact of customer satisfaction on pricing. Therefore, data from 2017 are used in order to focus only on satisfaction-pricing relationships.

The paper is organized as follows: Literature review on the role of customer online satisfaction in price determination is followed by the research methodology. After indepth literature review, the principal component analysis is conducted and the regression model is estimated using the extracted principal component. The conclusions with perspective for future research are provided in the final chapter.

\section{Literature review}

Öğüt and Onur Tas (2012) point out that online booking has a substantial share in overall hotel booking. The positive side of online booking is in the possibility to gain valuable information about hotels from previous consumers, including location, facilities as well as important intangible aspects such as comfort and attentiveness of 
staff. Previous customers are also able to share their experience with other potential consumers.

Recognizing the link between hotel ratings, online reviews and pricing is essential both for hotel managers and customers. Thus, the quantitative assessment of the mentioned relationship offers valuable results regarding the supply and the demand side in the hotel industry. The aim of this study is to investigate the role of customer online satisfaction in price determination in the Croatian hotel industry, where rating available at Booking.com approximates guest satisfaction.

The importance of the hotel characteristics in customer decisions making is widely researched in the literature (Öğüt, Onur Tas, 2012; Lewis, 1984; Bell, Morey, 1996; Callan, 1998; Lieux et al., 1994; McCleary et al., 1993; Lockyer, 2005). The survey methods are used to determine the important component for the hotel selection decision of the customer. The widely used components in these papers are location, service, price, room and hotel features, security, reputation and star rating. Using a focus group of 42 participants Lockyer (2005) outline that price should not be considered along with other characteristics but needs special consideration in accommodation selection.

Espinet et al. (2003) investigate the impact of the different characteristics or attributes of a holiday hotel in the sun-and-beach segment on prices. The effect was assessed using the hedonic function perspective by means of random effect models. The research revealed the noticeable price differences between the 4-star hotels and hotels of other categories. Furthermore, many attributes such as hotel size, distance to the beach and availability of own parking place indicated significant effect on the price.

Thrane (2007) estimates how the guest rating of selected hotel attributes is related to the room rates for single and double rooms in Oslo using seemingly unrelated regression and points to the positive impact of guest rating on hotel room price. Moreover, using linear regression modelling, Zhang et al. (2011) examine how guest rating of the room, namely quality, cleanliness, location and service influence room rates in hotels, and conclude that room quality and location are main determinants of room price for the industry. However, they outline that variables influencing room rates differ greatly among hotel segments. Pawlicz and Napierala (2017) point to the significant influence of star rating on the hotel prices. Hedonic price model is used in order to estimate the influence of different online travel agents (OTAs) and situational factors on hotel prices in Warsaw. In mentioned research, the relationship of prices provided by three different online travel agents and star ratings is explored. It is confirmed that hotel prices are influenced by star rating. Furthermore, every additional star enables the hotel to set approximately 25 to 36 per cent higher prices, similar to previous research. Also, the location within the centre and proximity to the international airport are two highly important, but still underrated factors regarding the theoretical hotel prices.

In line with the above-mentioned literature, Öğ̈̈t, and Onur Taş (2012) conclude that higher customer ratings significantly increase the online sales of hotels. They conclude that a $1 \%$ increase in online customer ratings increases sales per room up to $2.68 \%$ in Paris and up to $2.62 \%$ in London. They also find that the star rating of hotels significantly affects the sensitivity of room prices to customer ratings. Specifically, higher customer ratings have a stronger influence on the price in case of hotels with higher star ratings.

Also, Viglia et al. (2016) used regression analysis to investigate the determinants of hotel occupancy rates. They conclude that the online review score is the dimension with the highest impact on occupancy rates. Moreover, the higher number of 
reviews is increasing hotel occupancy, but also the strength of impact of reviews on hotel occupancy rates decreases as the number of reviews increases.

After overview of previous research, the effect of various guest satisfaction components on hotel room pricing is analysed. The guests' rating of cleanliness, comfort, location, facilities, staff, value for money and Wi-Fi connection are used in principal component analysis and one principal component is extracted. Finally, the conclusions with perspective for future research are provided. This research fills the gap in existing literature by using multivariate principal component analysis to group various customer satisfaction categories in the hotel industry and assessing the relationship between customer satisfaction and hotel price.

\section{Research methodology}

Data are retrieved from Booking.com as one of the largest travel booking sites in the world. The dataset includes all four and five-star hotels in Croatia listed on the page Booking.com. When guests check out, they commonly receive an email asking them to review their stay within 90 days. Guests are asked to rate the hotel in six specific areas: guest room cleanliness, comfort, location, facilities, attentiveness of staff, value for money, and paid WiFi. Guests who stayed in 195 four star and 45 five star hotels in Croatia in August 2017 thus selected the score from 1 to 10 to rate their satisfaction within each review category. Therefore, for the purpose of this research, data on room price per night in double room for breakfast and bed service (P), average customer rating (A) and customer rating for seven separate review categories, namely guest room cleanliness (X1), comfort (X2), location (X3), facilities (X4), attentiveness of staff (X5), value for money (X6) and paid WiFi (X7), are collected.

Firstly, the descriptive statistical analysis and the analysis of correlation matrix of selected variables are conducted, as preliminary steps to empirical research of the relationship between hotel room prices and customer satisfaction. It is expected that some of the ratings for seven mentioned categories might be highly correlated, i.e. the problem of multicollinearity might arise in multiple linear regression modelling. Therefore, principal component analysis is used to assess whether it is possible to group mentioned seven variables in a smaller number of components. Principal component analysis is often used to solve multicollinearity problem by combining variables that are collinear (see Field, 2011, Tabachnick, Fidell, 2007). The principal components analysis can be understood as a linear transformation of the original dependent variables into the new uncorrelated variables called principal components. Most of the information on variability of original data is related to first component, whereas the least refers to the last component.

The descriptive statistical measures of variables used in empirical analysis are shown in Table 1. While all variables related to customer rating exhibit low relative variability measured by coefficient of variation, room price per night denoted by $\mathrm{P}$ has coefficient of variation equal to $51.05 \%$, indicating much higher variability.

The correlation coefficients with corresponding p-values are shown in Table 2. All correlation coefficients are significant. Furthermore, Kinnear and Gray (2000) state that component analysis could be implemented if each variable has one or more correlation coefficients higher than or equal to 0.3. All observed significant coefficients are positive and higher than 0.3 for all pairs of variables, except price (P) and location (X3), price (P) and attentiveness of staff $(X 5)$, price $(P)$ and paid WiFi $(X 7)$ as well as location (X3) and paid WiFi (X7). For mentioned pairs correlation coefficients are significant, but lower than 0.3 . 
Table 1 Descriptive statistics of variables used in the analysis

\begin{tabular}{|c|c|c|c|c|c|c|c|c|c|}
\hline & $\mathrm{P}$ & $\mathrm{A}$ & $\mathrm{X} 1$ & $\mathrm{X} 2$ & $\mathrm{X} 3$ & $\mathrm{X} 4$ & $\mathrm{X} 5$ & $\mathrm{X6}$ & $\mathrm{X} 7$ \\
\hline Range & 3661.53 & 3.2 & 3.2 & 3.6 & 3.6 & 3.5 & 3 & 3.6 & 4 \\
\hline Minimum & 334 & 6.6 & 6.8 & 6.4 & 6.4 & 6.4 & 7 & 5.9 & 6 \\
\hline Maximum & 3995.53 & 9.8 & 10 & 10 & 10 & 9.9 & 10 & 9.5 & 10 \\
\hline Mean & 965.48 & 8.8 & 9.1 & 8.9 & 9.1 & 8.6 & 9.0 & 8.2 & 8.6 \\
\hline Std. Deviation & 492.93 & 0.53 & 0.63 & 0.67 & 0.55 & 0.65 & 0.56 & 0.58 & 0.84 \\
\hline Skewness & 2.029 & -0.777 & -0.964 & -0.763 & -0.977 & -0.656 & -0.582 & -0.537 & -0.860 \\
\hline Kurtosis & 6.780 & 1.075 & 1.035 & 0.498 & 1.817 & 0.369 & 0.316 & 1.056 & 0.776 \\
\hline Coefficient of variation & 51.05 & 6.10 & 6.99 & 7.62 & 6.06 & 7.48 & 6.28 & 7.11 & 9.76 \\
\hline
\end{tabular}

Source: authors' calculation.

Table 2 Correlation matrix of variables used in the analysis

\begin{tabular}{|c|c|c|c|c|c|c|c|c|}
\hline $\begin{array}{c}\text { Correlation } \\
\text { (p-value) }\end{array}$ & $P$ & $X 1$ & $\times 2$ & $\times 3$ & $\times 4$ & $\times 5$ & X6 & $X 7$ \\
\hline$P$ & 1 & & & & & & & \\
\hline $\mathrm{X} 1$ & $\begin{array}{l}0.373^{*} \\
(0.000)\end{array}$ & 1 & & & & & & \\
\hline $\mathrm{X} 2$ & $\begin{array}{l}0.400^{*} \\
(0.000)\end{array}$ & $\begin{array}{l}0.891^{*} \\
(0.000)\end{array}$ & 1 & & & & & \\
\hline X3 & $\begin{array}{l}0.286^{*} \\
(0.000)\end{array}$ & $\begin{array}{l}0.554^{*} \\
(0.000)\end{array}$ & $\begin{array}{c}0.502^{*} \\
(0.000)\end{array}$ & 1 & & & & \\
\hline $\mathrm{X} 4$ & $\begin{array}{l}0.411^{*} \\
(0.000)\end{array}$ & $\begin{array}{l}0.875^{*} \\
(0.000)\end{array}$ & $\begin{array}{l}0.947^{*} \\
(0.000)\end{array}$ & $\begin{array}{l}0.508^{*} \\
(0.000)\end{array}$ & 1 & & & \\
\hline $\mathrm{X5}$ & $\begin{array}{l}0.296^{*} \\
(0.000)\end{array}$ & $\begin{array}{l}0.834^{*} \\
(0.000)\end{array}$ & $\begin{array}{l}0.741^{*} \\
(0.000)\end{array}$ & $\begin{array}{l}0.548^{*} \\
(0.000)\end{array}$ & $\begin{array}{l}0.757^{*} \\
(0.000)\end{array}$ & 1 & & \\
\hline X6 & $\begin{array}{l}0.124^{*} \\
(0.024)\end{array}$ & $\begin{array}{l}0.801^{*} \\
(0.000)\end{array}$ & $\begin{array}{l}0.818^{*} \\
(0.000)\end{array}$ & $\begin{array}{l}0.500^{*} \\
(0.000)\end{array}$ & $\begin{array}{l}0.822 * \\
(0.000)\end{array}$ & $\begin{array}{l}0.810^{*} \\
(0.000)\end{array}$ & 1 & \\
\hline$X 7$ & $\begin{array}{l}0.233^{*} \\
(0.000)\end{array}$ & $\begin{array}{l}0.512^{*} \\
(0.000)\end{array}$ & $\begin{array}{l}0.511^{*} \\
(0.000)\end{array}$ & $\begin{array}{l}0.291^{*} \\
(0.000)\end{array}$ & $\begin{array}{l}0.534^{*} \\
(0.000)\end{array}$ & $\begin{array}{l}0.520^{*} \\
(0.000)\end{array}$ & $\begin{array}{l}0.483^{*} \\
(0.000)\end{array}$ & 1 \\
\hline
\end{tabular}

Note: * denotes significance of correlation coefficient at $5 \%$ level $(p<0.05)$. P-values for twoway test in parentheses.

Source: authors' calculation using SPSS 19.

Therefore, after the examination of correlation matrix, the principal component analysis is performed for all variables referring to customer rating for seven separate review categories, taking into consideration previously mentioned low correlation coefficients between location (X3) and paid WiFi (X7). Regarding the hotel industry, Dortyol et al. (2014) also analysed the relationship between the consumer satisfaction and other relevant attributes using the principal component analysis. The results of the conducted analysis, together with the estimation of regression models, are given in the next section.

\section{Results and discussion}

In order to decide how many components to retain, it is necessary to observe communalities. The communality is the proportion of common variance present within the variable (Field, 2011). When the number of variables in the analysis is less than 30 and the resulting communalities after extraction are all greater than 0.7, then Kaiser's criterion of retaining components with eigenvalues greater than 1 is accurate (Field, 2011). When all selected variables were included in principal component analysis, communalities for location (X3) and paid WiFi (X7) were lower than 0.7. Therefore, mentioned variables were excluded from further analysis. Furthermore, it is necessary to recall that correlation between these two variables is 
previously shown to be low. Principal component analysis is therefore conducted for variables guest room cleanliness (X1), comfort (X2), facilities (X4), attentiveness of staff (X5) and value for money (X6). Table 4 shows that communalities for all selected variables are higher than 0.7. Moreover, the Kaiser-Meyer-Olkin (KMO) measure of sampling adequacy (see Kaiser, 1970) calculated using SPSS 19 software equals 0.844 with $p$-value equal to 0.000 . Kaiser (1974) proposes values lower than 0.5 as hardly acceptable, between 0.5 and 0.7 as mediocre, between 0.7 and 0.8 as good and values between 0.8 and 0.9 as great, while values higher than 0.9 are considered superb.

Table 3 shows the eigenvalue related to each component before and after extraction. Before extraction, 5 linear components are related to 5 variables. The eigenvalues related to each component show the variance explained by that linear component and eigenvalues are also shown in terms of percentage of explained variance. It is evident that after extraction the first component explains $86.387 \%$ of total variance and each additional component low percentage of total variance. The criteria for component extraction are the eigenvalue higher than one and therefore one component is extracted out of 5 selected variables. The eigenvalue of the first component is higher than one and therefore one component which comprises guest satisfaction is retained.

Table 3 Total variance explained

\begin{tabular}{|c|c|c|c|c|}
\hline \multirow{2}{*}{ Component } & \multicolumn{3}{|c|}{ Initial Eigenvalues } & Extraction Sums of Squared Loadings \\
\cline { 2 - 5 } & Total & \% of Variance & Cumulative \% & Total \\
\hline 1 & 4.319 & 86.387 & 86.387 & 4.319 \\
\hline 2 & 0.331 & 6.626 & 93.013 & \\
\hline 3 & 0.205 & 4.093 & 97.106 & \\
\hline 4 & 0.096 & 1.920 & 99.026 & \\
\hline 5 & 0.049 & 0.974 & 100.000 & \\
\hline
\end{tabular}

Source: authors' calculation using SPSS 19.

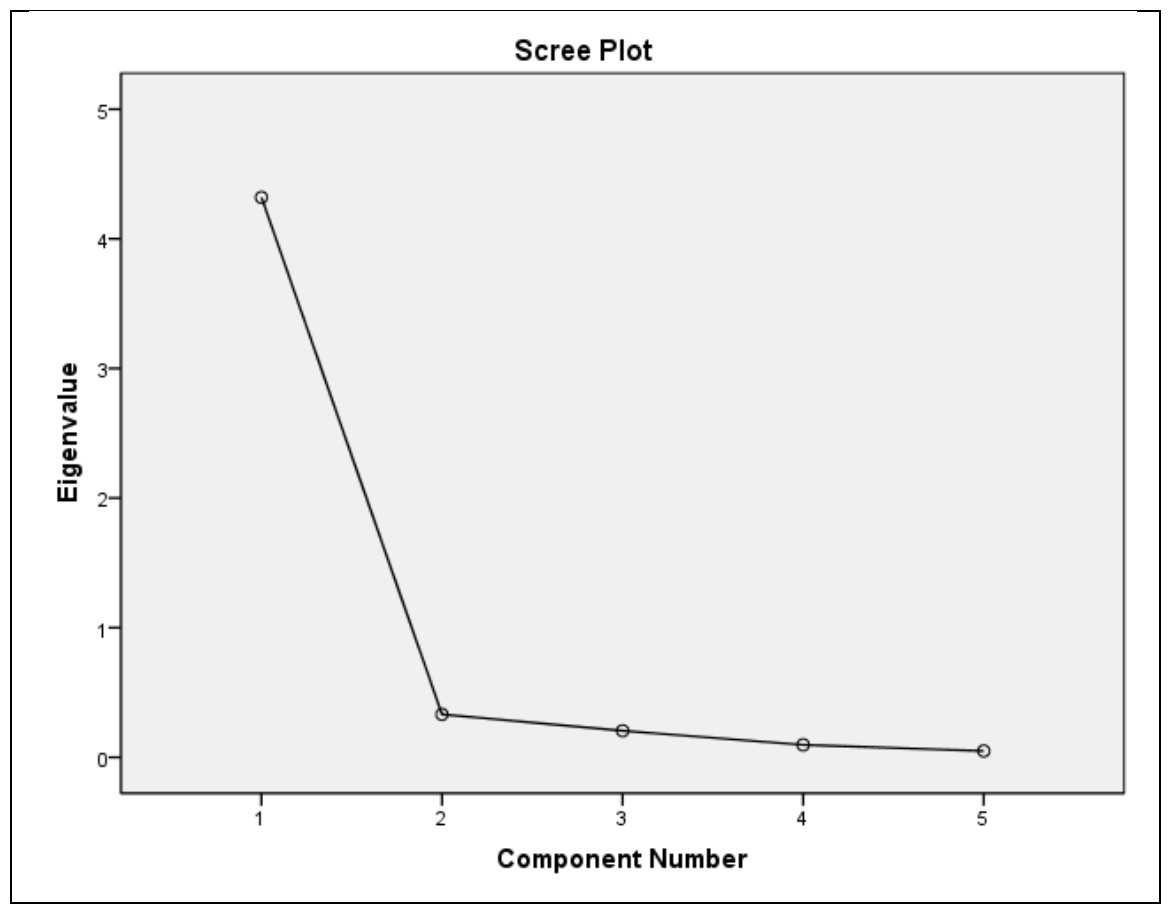

Figure 1 Scree plot

Source: authors' calculation using SPSS 19. 
The scree plot is Shown in Figure 1. This graphical representation advocated by Catell (1966) shows each eigenvalue on $Y$ axis against the corresponding component on $X$ axis. According to Catell (1966) the cut-off point is the inflexion point of the scree plot, what confirms that only one component should be retained.

Table 4 shows communalities before and after component extraction. Principal component analysis is based on the assumption that initially total variance associated with a variable is common and thus before extraction all communalities are equal to 1. Communalities after extraction show the proportion of common variance of each variable that can be explained by the retained component. Namely, after extraction $89.9 \%$ of variance associated to guest room cleanliness rating (X1) is common, or shared, variance. As previously stated, Kaiser's criterion of retaining components with eigenvalues greater than 1 is accurate since communalities after extraction are all greater than 0.7 .

Table 4 Initial communalities and communalities after extraction for selected variables

\begin{tabular}{|c|c|c|}
\hline Variable & Communality before extraction & Communality after extraction \\
\hline $\mathrm{X} 1$ & 1.000 & 0.899 \\
\hline $\mathrm{X} 2$ & 1.000 & 0.897 \\
\hline $\mathrm{X} 4$ & 1.000 & 0.900 \\
\hline $\mathrm{X} 5$ & 1.000 & 0.790 \\
\hline $\mathrm{X} 6$ & 1.000 & 0.833 \\
\hline
\end{tabular}

Source: authors' calculation using SPSS 19.

The component matrix is shown in Table 4. All selected variables are positively related to one extracted component and loadings are presented in the table. The extracted component is related to guest satisfaction and it is denoted by GS. After the principal component analysis has shown that one component properly comprises the original set of variables, the extracted component GS is used in linear regression modelling. Regarding the use of principal components analysis, Vajčnerova et al. (2012) estimated level of a consumer satisfaction by evaluating the quality of a tourist destination and used the principal component analysis due to the large number of dependent variables. Radojevic et al. (2014) also estimated the expectations of hotel guests in relation to the services offered by the hotel using the principal component analysis.

After the extraction of one component which refers to guest satisfaction, two initial linear regression models are estimated. Firstly, the impact of guest satisfaction on hotel room pricing is analysed. Data on room price per night in double room for breakfast and bed service (P) are given in natural logarithm values and denoted by LP. The logarithmic transformation is conducted in order to avoid residual heteroskedasticity problem (Enders, 2010). Therefore, in Model 1 variable LP is the dependent variable, while the independent variable is the previously extracted component which refers to guest satisfaction denoted by GS. The following linear regression equation is estimated, with corresponding t-values in brackets:

$$
\begin{gathered}
L P=6.7489+0.1469 G S \\
(263.66)(5.44)
\end{gathered}
$$

Model 1 points to the conclusion that guest satisfaction in Croatia has a statistically significant positive impact on hotel room price, which is in line with previous relevant research. The White test chi-square test statistic $\chi^{2}=5.9855$, with corresponding $\mathrm{p}$-value of 0.0501 , while for the second model $\chi^{2}=6.1469$, with $\mathrm{p}$-value 
of 0.056 which indicates that the null hypothesis of homoscedasticity cannot be rejected at $5 \%$ significance level. Regarding the residual autocorrelation test, for both models the Ljung-Box test of autocorrelation is conducted using EViews 9. The null hypothesis of no autocorrelation of residuals cannot be rejected up to lag length $k=36$ at $5 \%$ significance level, since all corresponding empirical significance levels are higher than 0.05. Moreover, the Jarque-Bera test of residual normality is conducted. For the first model, the Jarque-Bera test statistic equals 2.6032, with p-value of 0.2721 , indicating that the null hypothesis of residual normal distribution cannot be rejected at any reasonable significance level. For the second model, JB=6.358 with $\mathrm{p}$-value of 0.052, pointing to the conclusion that the null hypothesis of residual normal distribution cannot be rejected at $5 \%$ significance.

Furthermore, the estimation is done separately for four-star hotels and for five-star hotels. Model 2 is estimated with LP as the dependent variable and GS as the independent, but only for 195 four-star hotels (excluding five-star hotels) and the following result is obtained:

$$
\begin{gathered}
\text { LP } 4^{*}=6.6665+0.1077 G S 4^{*} \\
(256.55)(4.02)
\end{gathered}
$$

Accordingly, Model 3 consists of the same variables as Model 2, but for different sample, thus it is estimated for 45 five-star hotels and the following regression equation is estimated:

$$
\mathrm{LP}^{*}=7.1355+0.1956 \mathrm{GS} 5^{*}
$$

The impact of guest satisfaction on hotel price is positive in both Model 2 and Model 3. However, the impact in Model 3 with five-star hotels is almost twice as strong as in Model 2 with four-star hotels. Moreover, for Model 2 the coefficient of determination $R^{2}=0.0771$, while for Model 3 the $R^{2}=0.2763$, pointing to the better representativeness of the model in case of the inclusion of only five-star hotels in the analysis. In other words, the proportion of the error explained by the model is much higher in Model 3 with five-star hotels included than for Model 2 which includes only four-star hotels.

The assessment of the assumptions of estimated regression models is conducted. For Model 2 the White heteroskedasticity test $\chi^{2}=3.024$ with $p$-value of 0.2204 , while for Model $3 \chi^{2}=1.828$ with p-value of 0.4009 , and thus heteroskedasticity is not present at any reasonable significance level. The Jarque-Bera normality test is conducted. For Model 2, JB=2.7473 with $\mathrm{p}$-value of 0.2532 and for Model 3, JB=1.0619 with $\mathrm{p}$ value of 0.588 , pointing to the normal distribution of residuals at any reasonable significance level. Concerning the Ljung-Box test of autocorrelation, the residual autocorrelation problem is not present neither in Model 2 nor in Model 3 at $5 \%$ significance.

Obtained results are in line with previous research of hotel room pricing determinants in London and Paris conducted by Öğüt and Onur Taş (2012). Their research pointed out that higher customer ratings significantly increase the online sales of hotels. They concluded that a $1 \%$ increase in online customer ratings increases sales per room up to $2.68 \%$ in Paris and up to $2.62 \%$ in London. They also find that the star rating of hotels affects the sensitivity of room prices to customer ratings. Specifically, higher customer ratings have a stronger influence on the price in case of hotels with higher star rating. 


\section{Conclusion}

The results point to the positive statistically significant impact of customer satisfaction approximated by online ratings on pricing in Croatian hotels with four and five stars. Moreover, the estimated impact is twice as strong for five-star hotels in relation to four-star hotels.

The conducted research provides captivating results for tourism and overall economic policy makers, as well as for managers and customers. The analysis of guest satisfaction and price determination in the hotel industry is of great importance in a small open economy with a developed tourism sector. Regarding the importance of the tourism sector in Croatia, the direct contribution of travel and tourism to GDP amounted to USD 5,447.7 million in 2016 which represents $10.7 \%$ of total GDP. Total contribution of travel and tourism to GDP in 2016 was USD 12,534.4 million, i.e. $24.7 \%$ of GDP. Additionally, the importance of tourism indicates that visitor exports generated USD 9,776.2 million, which accounts for $38 \%$ of total exports in 2016 (World Travel and Tourism Council, 2017).

Furthermore, online customer reviews provide valuable information for making hotel reservations. Potential customers often consider online ratings prior to making hotel reservations, even if they are not making the reservation online. Furthermore, the growing adoption of mobile booking applications intensifies the online rating importance. Since online reviews are considered autonomous, customers strongly rely on them when making reservations (PricewaterhouseCoopers, 2015). The Internet allows customers to access accurate information, as well as the possibility of making reservations faster with lower expenses than in relation to conventional methods.

The assessment of the relationship between online reviews and pricing is necessary for appropriate price determination in the hotel industry. Moreover, the finding that online reviews are important for price determination might also influence customers. Hotels with more loyal and satisfied guests are able to charge higher prices due to the experience they offer. In line with that, higher price paid increases guests' expectations of higher quality. This paper provides valuable conclusions both from the aspect of the supply and the demand side in the hotel industry.

However, there are certain limitations of empirical research in the paper. For instance, data was collected from only one website (www.booking.com), which could reflect research bias if there are differences in the prices offered on other websites. Also, a more disaggregated approach, in which hotels would be geographically segmented, could be applied in future research. Furthermore, the assessment of the relationship between guest satisfaction and hotel price using data on hotels with less than four stars could contribute to the relevance of the conducted analysis. Moreover, it would be interesting to conduct the analysis taking into account different categories of clients. Also, regarding the methods used, it would be interesting to use the extracted factors with two components in following research.

\section{References}

1. Bell, R. A., Morey, R. C. (1996). Purchase situation modelling: The case of hotel selection criteria for corporate travel departments. Journal of Travel Research, Vol. 35, No.1, pp. 5763.

2. Bojanic, D. C. (1996). Consumer perceptions of price, value and satisfaction in the hotel industry: An exploratory study. Journal of Hospitality \& Leisure Marketing, Vol. 4, No. 1, pp. 5-22. 
3. Bolton, R. N., Lemon K. N. (1999). A Dynamic Model of Customer's Usage of Services: Usage as an Antecedent and Consequence of Satisfaction. Journal of Marketing Research, Vol. 36, pp. 171-186.

4. Callan, R. (1998). Attributional analysis of customer's hotel selection criteria by UK grading scheme theories. Journal of Travel Research, Vol. 36, No. 3, pp. 20-34.

5. Cattell, R. B. (1966). The scree test for the number of factors. Multivariate Behavioral Research, Vol. 1, pp. 245-276.

6. Dortyol I., Varinli I., Kitapci O. (2014). How do international tourists perceive hotel quality?: An exploratory study of service quality in Antalya tourism region. International Journal of Contemporary Hospitality Management, Vol. 26, No. 3, pp. 470-495.

7. Enders, W. (2010). Applied Econometric Time Series. John Wiley and Sons, London.

8. Espinet, J. M., Saez, M., Coenders, G., Fluvià, M. (2003). Effect on prices of the attributes of holiday hotels: a hedonic prices approach. Tourism Economics, Vol. 9, No. 2, pp. 165-177.

9. Farris, P., Bendle, N., Pfeifer, P., Reibstein, D. (2015). Marketing Metrics: The Manager's Guide to Measuring Marketing Performance. Pearson Education, New Jersey.

10.Field, A. (2011). Discovering statistics using SPSS. Sage, London.

11.Gronholdt, L., Martensen, A., Kristensen, K. (2000). The Relationship between Customer Satisfaction and Loyalty: Cross-Industry Differences, Total Quality Management, Vol. 11 , pp. 509-514.

12.Homburg, C., Koschate, N., Hoyer, W. D. (2005). Do Satisfied Customers Really Pay More? A Study of the Relationship between Customer Satisfaction and Willingness. Journal of Marketing, Vol. 69, No. 2, pp. 84-96.

13.Kaiser, H. F. (1974). An index of factorial simplicity. Psychometrika, Vol. 39, pp. 31-36.

14.Kinnear, P., Gray, C. D. (2000). SPSS for Windows Made Simple. Psychology Press, Have.

15.Lewis, R. (1984). Isolating differences in hotel attributes. Cornell Hotel and Restaurant Administration Quarterly, Vol. 25, No. 3, pp. 64-77.

16.Lewis, R. C., Shoemaker, S. (1997). Price-sensitivity measurement: A tool for the hospitality industry. Cornell Hotel and Restaurant Administration Quarterly, Vol. 38, No. 2, pp. 44-54.

17.Lieux, E. M., Weaver, P. A., McCleary, K. (1994). Lodging preferences of the senior tourism market. Annals of Tourism Research, Vol. 21, No. 4, pp. 712-728.

18.Lockyer, T. (2005). The perceived importance of price as one hotel selection dimension. Tourism Management, Vol. 26, No. 4, pp. 529-537.

19.Mattila, A., O'Neill, J. (2003). Relationships between Hotel Room Pricing, Occupancy, and Guest Satisfaction: A Longitudinal Case of a Midscale Hotel in the United States. Journal of Hospitality \& Tourism Research, Vol. 27, No. 3, pp. 328-341.

20.Matzler K., Renzl B., Rothenberger S. (2006). Measuring the Relative Importance of Service Dimensions in the Formation of Price Satisfaction and Service Satisfaction: A Case Study in the Hotel Industry. Scandinavian Journal of Hospitality and Tourism, Vol. 6, No. 3, pp. 179196.

21.Matzler, K., Würtele, A., Renzl. B. (2006). Dimensions of price satisfaction: a study in the retail banking industry. International Journal of Bank Marketing, Vol. 24, No. 4, pp. 216-231.

22.McCleary, K., Weaver, P., Lan, L. (1993). Hotel selection factors as they relate to business travel situation. Journal of Travel Research, Vol. 32, No. 2, pp. 42-48.

23.Öğüt, H., Onur Taş, B. K. (2012). The influence of internet customer reviews on the online sales and prices in hotel industry. The Service Industries Journal, Vol. 32, No. 2, pp. 197-214.

24.Pawlicz, A., Napierala, T. (2017). The determinants of hotel room rates: an analysis of the hotel industry in Warsaw, Poland. International Journal of Contemporary Hospitality Management, Vol. 29, No. 1, pp. 571-588.

25.PricewaterhouseCoopers (2015). Online reputations: Why hotel reviews matter and how hotels respond. Available at https://www.pwc.com/gx/en/hospitality-leisure/pdf/globalhotel-report-2015.pdf [14 May 2019].

26.Radojevic, T., Stanisic, N., Stanic, N., Sarac, M. (2014). Measuring customer satisfaction in the hospitality industry: an empirical study of the hotels in the capital cities of Europe. In The 2014 Proceedings of the first international Conference Sinteza, Belgrade.

27.Steffes, E., Burgee, L. (2009). Social ties and online word of mouth. Internet Research, Vol. 19, pp. $42-59$. 
28.Tabachnick, B. G., Fidell, L. S. (2007). Using multivariate statistics. Allyn \& Bacon, Boston.

29. Thrane, C. (2007). Examining the determinants of room rates for hotels in capital cities: The Oslo experience. Journal of Revenue and Pricing Management, Vol. 5, No. 4, pp. 315-323.

30.Vajčnerova I., Šacha J., Ryglova K. (2012). Using the principal component analysis for evaluating the quality of a tourist destination. Acta universitatis agriculturae et silviculturae mendelianae brunensis, Vol. 60, No. 2, pp. 449-458.

31.Viglia, G., Minazzi, R., Buhalis, D. (2016). The influence of e-word-of-mouth on hotel occupancy rate. International Journal of Contemporary Hospitality Management, Vol. 28, No. 9, pp. 2035-2051.

32. World Travel and Tourism Council (2017). The Economic Impact of Travel \& Tourism Croatia. Available at https://www.wttc.org/-/media/files/reports/economic-impactresearch/countries-2017/croatia2017.pdf [15 May 2019].

33.Zhang, Z., Ye, Q., Law, R. (2011). Determinants of hotel room price: An exploration of travelers' hierarchy of accommodation needs. International Journal of Contemporary Hospitality Management, Vol. 23, No. 7, pp. 972-981.

\section{About the authors}

Irena Palić, PhD is employed as Assistant Professor at the Department of Statistics, Faculty of Economics and Business, University of Zagreb, where she teaches "Statistics", "Business statistics" and "Statistical methods in professional and scientific work". She gained a PhD degree in Economics in 2015 at the Faculty of Economics and Business, University of Zagreb. Her main research interests are the application of statistics and econometrics in business, finance and economics. She is an active researcher of the Croatian Science Foundation project "Empowering financial capability of young consumers through education and behavioural intervention ". She was the leader of the University of Zagreb scientific project "Statistical modelling of the impact of financial education on consumer attitudes and behaviour" from 2018 to 2020. Author can be contacted at ipalic@efzg.hr.

Petra Palić, PhD is employed as Assistant Professor at the Department of Sociology, Catholic University of Croatia, where she teaches "Principles of Economics", "Microeconomics", "Macroeconomics" and "Public choice theory". Also, she collaborates as external Assistant Professor at the Department of Finance where she teaches "Monetary policy" and "Public finance". She gained a PhD degree in Economics in 2018 at the Faculty of Economics and Business, University of Zagreb. Her main research interests are international finance, macroeconomics, microeconomics and social policy. She was a doctoral researcher of the Croatian Science Foundation project "Economic, statistical and political aspects of sovereign bond markets - SOBOM", from 2015 to 2018. Author can be contacted at petra.palic@unicath.hr.

Frane Banić, MA is employed as Economist Researcher-Associate at the Economic Analysis Department, Croatian National Bank, where he participates in monitoring and analyzing developments in the real sector and public finance for CNB regular publications (monthly, semiannual and annual reports). Also, he is managing databases as well as using statistical methods for macroeconomic analysis. His main research interest are public finance, macroeconomics and the application of econometrics in fiscal policy. He is currently a PhD Student at the Faculty of Economics and Business, University of Zagreb. Author can be contacted at frane.banic@hnb.hr. 